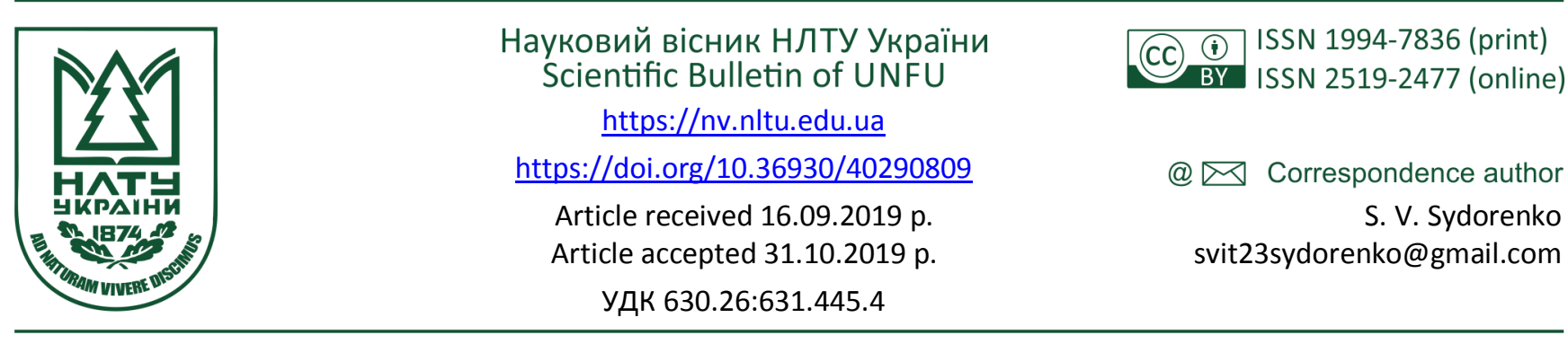

С. В. Сидоренко ', О. І. Старченко ${ }^{2}$ Г. Б. Гладун ${ }^{3}$, С. Г. Сидоренко 1

${ }^{l}$ Український НДІ лісового господарства і агромеліорачії ім. Г. М. Висоиького, м. Харків, Украӥна ${ }^{2}$ Національний науковий центр "Інститут агрохімії та трунтознавства ім. О. Н. Соколовського", м. Харків, Украйна ${ }^{3}$ Харківський національний технічний університет сільського господарства ім. П. Василенка, м. Харків, Україна

\title{
ВПЛИВ ЛІНІЙНИХ ДУБОВИХ ПОЛЕЗАХИСНИХ НАСАДЖЕНЬ НА БІОГЕННІСТЬ ЧОРНОЗЕМУ ТИПОВОГО АГРОГЕННОГО ВИКОРИСТАННЯ
}

Розглянуто особливості біогенності грунту в умовах сільськогосподарського освоєння в зоні впливу полезахисної лісової смуги. Зазначено особливий режим інтенсивності та спрямованості мікробіологічних процесів порівняно 3 відкритим полем, яке було контролем порівняно з лісовим фітоценозом. Оцінено біологічну активність грунту за чисельністю та співвідношенням основних агрономічно важливих груп мікроорганізмів чорнозему типового. Встановлено тенденцію щодо активізації просторової структури мікробного ценозу в напрямку від узлісся смуги і до центру поля: зі збільшенням відстані від смуги зростає чисельність оліготрофів, що свідчить про збільшення частини легкодоступних органічних сполук. Серед усіх груп найбільшу чисельність виявлено серед оліготрофних мікроорганізмів (максимальна - 29,22 млн КУО/г грунту з завітряного боку лісової смуги, мінімальна - 22,94 млн КУО/г грунту з навітряного боку). Значна чисельність мікроорганізмів, які засвоюють мінеральний азот (18,56-24,56 млн КУО/г грунту), було зосереджено як із завітряного, так і 3 навітряного боків. Такі показники зумовлені застосуванням агротехнічних прийомів на міжсмуговому полі порівняно з полезахисною смугою, де будь-які агротехнічні заходи не вживаються з часу їх створення. Виявлено сприятливі умови накопичення органічної речовини за показником мінералізації на відстані від лісової смуги $10 \mathrm{H}$, що свідчить про оптимізацію процесів мінералізації грунту. За допомогою коефіцієнтів трансформації виявлено порушення грунтоутворювальних процесів на ріллі та їхню розбалансованість. Встановлено, що показник мікробної трансформації органічної речовини грунту в зоні дослідження мав тенденцію до зменшення на більшій відстані від лісової смуги.

Ключові слова: полезахисна лісова смуга; еколого-трофічні угруповання; біогенність грунту; захисна висота; навітряний бік; завітряний бік.

Вступ. В Україні внаслідок порушення науково обгрунтованих технологій сільськогосподарського виробництва стан грунтів неупинно погіршується й інтенсифікуються процеси ерозії, засолення, дегуміфікації. Порушення природного функціонування грунтового покриву є проблемою міжнародного рівня, а їхня охорона - однією з важливих екологічних проблем. Сільськогосподарські землі України у загальній структурі земельного фонду становлять майже $71 \%$, а рівень їх розораності - 78 \%, що є одним із найбільших серед європейських держав (Natsionalna dopovid, 2012).

Відомо, що в Україні для господарського використання залучено понад 92 \% території. Площа ріллі становить 32,5 млн га, з яких близько 16 млн га земель еродовані, а втрати гумусу на цих землях уже досягли рівня 30-70\% (Stratehiia, 2017). Серед деградаційних процесів впродовж останніх років на землях України домінує ерозія, якою охоплено 14,9 млн га земель (32 \% загальної площі сільськогосподарських угідь), iз них 10,6 млн га орнопридатні продуктивні землі (Budziak, 2014). Грунт, як складова біогеоценозу, знаходиться під впливом різного за часом, інтенсивністю та масштабом антропогенного навантаження (Shah et al., 2017; Hakeem et al., 2016), яке порушує нормальний перебіг грунтових процесів та призводить до значних змін у функціонуванні мікробного угруповання (Patyka 2013; Bardgett and van der Putten, 2014; Wall et al., 2015).

Напрям досліджень мікробіологічних процесів грунту, де важливим компонентом біологічного кругообігу речовин є грунтові мікроорганізми (Doni et al., 2017), на сучасному етапі розвитку агролісомеліорації тільки набуває розвитку (Notaro et al., 2014; Muhammed et al., 2015; Horyelov 2017). Вивчення біологічної активності грунту дає змогу глибше зрозуміти і виявити закономір-

\section{Інформація про авторів:}

Сидоренко Світлана Вікторівна, мол. наук. співробітник, лабораторія лісових культур та агролісомеліорації.

Email: svit23sydorenko@gmail.com; https://orcid.org/0000-0003-1426-7614

Старченко Олена Іванівна, канд. біол. наук, ст. наук. співробітник, завідувач сектору мікробіології ґрунтів.

Email: elena.starchenkoua@gmail.com

Гладун Григорій Борисович, д-р с.-г. наук, професор, кафедра деревооброблювальних технологій та системотехніки лісового комплексу. Email: gladun_g@ukr.net; https://orcid.org/0000-0001-8762-5684

Сидоренко Сергій Григорович, канд. с.-г. наук, ст. наук. співробітник, лабораторія екологіï. Email: serhii88sido@gmail.com

Цитування за ДСТУ: Сидоренко С. В., Старченко О. І., Гладун Г. Б., Сидоренко С. Г. Вплив лінійних дубових полезахисних насаджень на біогенність чорнозему типового агрогенного використання. Науковий вісник НЛтУ України. 2019, т. 29 , № 8. С. 60-65.

Citation APA: Sydorenko, S. V., Starchenko, O. I., Hladun, H. B., \& Sydorenko, S. H. (2019). The influence of oak shelterbelts on the biogenesity of typical agrogenic chornozem (black soil). Scientific Bulletin of UNFU, 29(8), 60-65. https://doi.org/10.36930/40290809 
ності у процесах перетворення органічної речовини, враховуючи антропогенний вплив на грунт та його властивості (Stratehiia, 2012; Murthy et al., 2016).

Розміщення лінійних насаджень на сільськогосподарських землях позитивно впливає на всі природні процеси, зокрема кругообіг органічної речовини та енергетичні потоки між елементами агроландшафту (Von Holle et al., 2006; Lisovyi \& Chaika, 2008; Bieliñska et al., 2008; Rempel et al., 2016; Coe et al., 2016). Полезахисні лінійні насадження також мають вплив на мікроклімат поля та грунтове середовище, ініціюючи зміни популяцій мікроорганізмів (Gu et al., 2002), які формують біологічно активні грунти. Мікробна біомаса в процесі іiі життєдіяльності в грунті сприяє мінералізації рослинних решток 3 утворенням доступних для рослин елементів живлення і $є$ важливим компонентом грунтового середовища (Kryhanivskyi \& Kostohryz, 2010). Вплив систем полезахисних насаджень на формування і функціонування мікробного комплексу грунту $є$ мало вивченим (Cavagnaro et al., 2016) і потребує додаткових досліджень для уточнення напрямів та інтенсивності мікробіологічних процесів на чорноземних грунтах України.

Об'єктом дослідження є грунт (чорнозем типовий) під лісовими смугами та на різній відстані від них. Предметом дослідження є зміни у чисельності грунтових мікроорганізмів та спрямованість мікробіологічної активності в грунті на різній відстані від полезахисної лісової смуги. Завдання роботи - визначити можливість впливу сформованого дубовою лісовою смугою лісового середовища на перебіг мікробіологічних процесів у верхньому шарі грунту.

Метою роботи є дослідження агроекологічного впливу дубової полезахисної лісової смуги на показники біогенності чорнозему типового глибокого важкосуглинкового на лесі в агроценозах Лівобережного Лісостепу України.

Матеріал і методи дослідження. Грунтово-біологічні дослідження виконували в природних умовах Лівобережного Лісостепу України на початку вегетації у травні 2014 р. Грунтовий покрив дослідної території складає чорнозем типовий (глибокий) важкосуглинковий на лесових породах. Досліджували верхній (030 см) шар грунту, де інтенсивно відбуваються процеси грунтоутворення під впливом рослинності та аеробних грунтових організмів.

Зразки грунту відібрано на різних відстанях від лісової смуги № 61 у дослідному господарстві ННВЦ "Дослідне поле" Харківського національного аграрного університету ім. В. В. Докучаєва. Полезахисна лісова смуга № 61 складається 3 4-х рядів, склад насадження 7Дз3Клг, віком 60 років. Середня висота дерев у смузі 22,8 м, діаметр - 28,9 см, повнота - 0,85, конструкція щільна. Зразки грунту відбирали в смузі, а також на різних відстанях від смуги. Забори зразків проводили з завітряного боку через: $1 H, 2 H, 5 H, 7 H$ та $10 H$, а також 3 навітряного через: $1 H, 2 H, 5 H$. Контролем було відкрите поле поза межами лісомеліоративного впливу цього насадження.

Біогенність грунтів визначали за чисельністю еколого-трофічних груп методом мікробного посіву на тверді поживні середовища (ДСТУ ISO 7847:2015), а саме: органотрофних бактерій - на м'ясо-пептоновий агар
(МПА), мікроорганізмів, що засвоюють азот мінеральних сполук, і актиноміцетів - на крохмаль-амонійний агар (КАА), оліготрофних мікроорганізмів - на голодний агар (ГА) (повторність 4-кратна: кожен грунтовий зразок висівали на живильне середовище в 4 паралельні чашки Петрі), грибів - на середовище Ріхтера (повторність 4-кратна). Мікробіологічний аналіз здійснювали на обладнанні сектора мікробіології грунтів лабораторії охорони та раціонального використання земель ННЦ "Інститут грунтознавства та агрохімії ім. О. Н. Соколовського".

Інтегровані показники, зокрема мінералізації (Mishustin, 1975), оліготрофності (Aristovskaya, 1977) та мікробної трансформації органічної речовини грунту (МТОРГ) (Muha, 1980), які характеризують напруженість мінералізаційних процесів i трофічний режим грунту, розраховували за співвідношенням окремих груп мікроорганізмів; інтегрований показник біогенності (ІПБ) - за методикою Дж. Ацці на основі розрахунку сумарного біологічного показника (СБП) (Atstsy, 1959).

Результати дослідження та їх обговорення. Як видно $з$ досліджень, які виконали деякі автори (Kovalov et al., 2012), та підтверджено нашими даними, на вміст органічних сполук азоту в грунтах впливає кількість органічної речовини. Мікробіологічні дослідження довели, що чисельність мікроорганізмів усіх досліджуваних еколого-трофічних груп у грунті як під наметом полезахисної лісової смуги, так і з її завітряного та навітряного боків мали мінімальні значення відносно всіх варіантів для насадження (табл. 1). Однак спостерігали деякі відмінності щодо органотрофних мікроорганізмів. Їхня чисельність виявилася дещо вищою в грунті під лісовою смугою - 11,15 млн КУО/г грунту (колонієутворювальних одиниць на 1 г абсолютно сухого грунту). Це пояснюємо хронологією формування і розвитку лісового ценозу в лінійних насадженнях, а саме збагаченням грунту більшою кількістю розкладених рослинних решток та елементами живлення органічного походження. Чисельність мікроорганізмів, які використовують органічні форми азоту, спостерігали найменшою на відстані 1-2 Н від полезахисної смуги як 3 навітряного, так і з завітряного боку, і коливалася у межах 7,49-9,25 млн КУО/г грунту. Саме ця зона відокремлення лісової смуги та ріллі, на якій відбуваються погіршення екологічних умов для сільськогосподарських культур, а для рудеральних видів рослинності, навпаки, складаються кращі умови, ми у своїй роботі назвали умовно "зоною пригнічення".

У цій зоні внаслідок впливу лісової смуги формуються особливі мікрокліматичні умови. Східноавстралійські дослідники Sudmeyer, Bicknell \& Coles (2007) у своїй роботі назвали цю зону конкурентною, оскільки в ній зазвичай знижується врожайність сільськогосподарських культур на відстані 2-4 $H$ від узлісся захисного насадження. Зона конкуренції відповідає бічній межі поширення коренів дерев, що тісно пов'язано зі зниженням грунтових вод, особливо в посушливі роки. Sven Erik Jørgensen (2009) аналогічно зауважив щодо обмеження вологості, однак і наголосив на тому, що ступінь конкуренції може змінюватись залежно від видів сільськогосподарських культур, деревних порід, географічного розташування та особливостей погодних умов. 
Табл. 1. Чисельність мікроорганізмів головних еколого-трофічних груп та розрахункові показники у горизонтах чорнозему типового на різних відстанях до/від лісової смуги

\begin{tabular}{|c|c|c|c|c|c|c|c|c|}
\hline \multirow{3}{*}{$\begin{array}{c}\text { Відстань від } \\
\text { лісової смуги, } \\
\text { Н }\end{array}$} & \multirow{3}{*}{ Бік } & \multicolumn{3}{|c|}{$\begin{array}{c}\text { Мікроорганізми, що засвоюють азот } \\
\text { (млн КУО/г грунту): }\end{array}$} & \multirow{3}{*}{$\begin{array}{c}\text { Гриби } \\
\text { (млн } \\
\text { КУО/г } \\
\text { грунту) }\end{array}$} & \multirow{3}{*}{\begin{tabular}{|l} 
Оліготро- \\
фи, (млн \\
КУО/г \\
грунту)
\end{tabular}} & \multirow{3}{*}{$\begin{array}{c}\text { Сумарна біоло- } \\
\text { гічна активність } \\
\text { (млн КУО/Г } \\
\text { грунту) }\end{array}$} & \multirow{3}{*}{$\begin{array}{c}\text { Інтегрований } \\
\text { показник } \\
\text { біогенності } \\
\text { ІПБ, \% }\end{array}$} \\
\hline & & \multirow{2}{*}{$\begin{array}{l}\text { органічний } \\
\text { (МПА) }\end{array}$} & \multicolumn{2}{|c|}{ мінеральний (КАА) } & & & & \\
\hline & & & всього & бактерії & & & & \\
\hline 10 & завітряний & 10,03 & 20,54 & 13,17 & 20,87 & 27,50 & 58,07 & 76,52 \\
\hline 7 & завітряний & 11,28 & 18,36 & 10,76 & 20,01 & 29,22 & 58,86 & 79,78 \\
\hline 5 & завітряний & 11,05 & 18,56 & 12,48 & 18,61 & 26,27 & 55,88 & 72,10 \\
\hline 2 & завітряний & 8,38 & 13,49 & 5,94 & 33,86 & 16,54 & 38,41 & 57,53 \\
\hline 1 & завітряний & 7,49 & 10,32 & 4,78 & 19,81 & 13,15 & 30,96 & 48,43 \\
\hline 0 & у смузі & 11,15 & 10,68 & 5,31 & 9,76 & 12,46 & 34,29 & 51,36 \\
\hline 1 & навітряний & 8,10 & 11,20 & 5,70 & 20,5 & 13,50 & 32,80 & 46,18 \\
\hline 2 & навітряний & 9,25 & 15,96 & 5,80 & 33,02 & 15,37 & 40,58 & 51,42 \\
\hline 5 & навітряний & 12,50 & 24,56 & 13,73 & 37,25 & 22,94 & 60,00 & 95,70 \\
\hline Відкрите поле & контроль & 8,90 & 15,30 & 14,10 & 14,50 & 25,60 & 49,80 & 66,90 \\
\hline$H I P_{05}$ & - & 2,67 & 3,48 & 4,18 & 3,84 & 3,66 & 9,54 & 13,32 \\
\hline
\end{tabular}

Виявлено прямий помірний зв'язок (рисунок) між відстанню від лісової смуги та чисельністю мікроорганізмів, які використовують органічні форми азоту: завітряного боку $-R^{2}=0,43 ; r=0,66 ; n=18 ; p=0,05$; навітряного боку $-R^{2}=0,62 ; r=0,79 ; n=12 ; p=0,05$, на проміжку 0-2 $H$ їхня чисельність була достовірно меншою. Тобто чисельність органотрофів була вищою у грунті лісової смуги, що пояснюємо формування специфічного лісового середовища під іiі наметом та інтенсивністю надходження органічних речовин з опаду. Таким чином можна стверджувати, що в напрямку до центру поля спостерігаємо активізацію мікробного ценозу у грунті. Це пояснюємо активним багаторічним використанням сільськогосподарських земель і формуванням специфічного мікробоценозу.

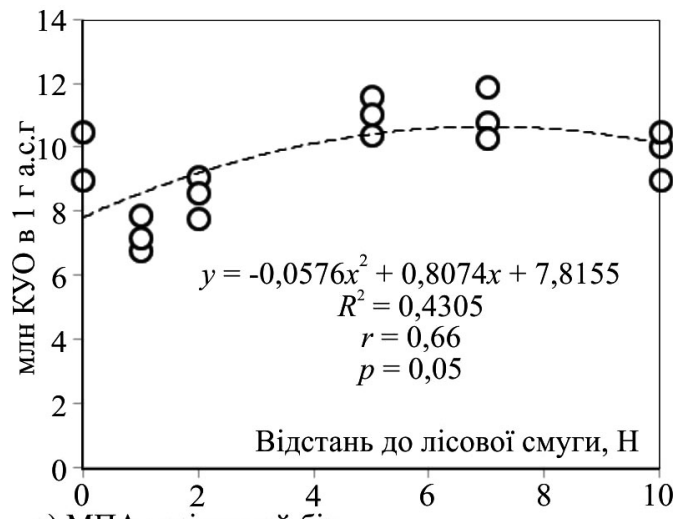

a) МПА завітряний бік

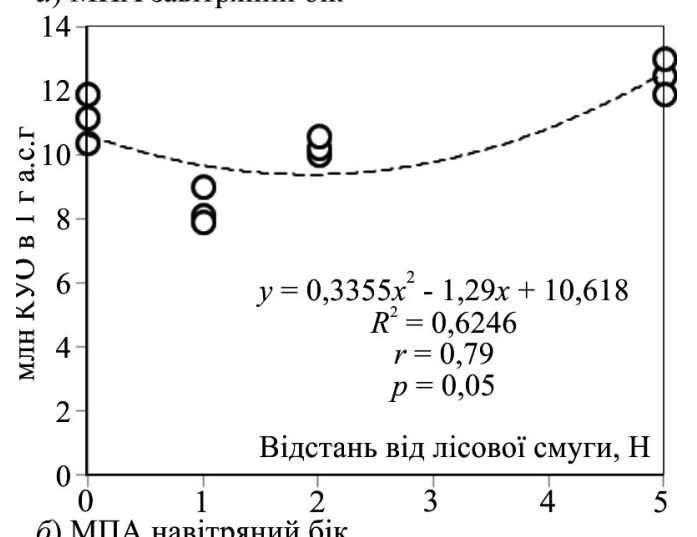

б) МПА навітряний бік

Рисунок. Чисельність органотрофів (МПА) залежно від відстані до/від полезахисної лісової смуги

Збільшення чисельності органотрофів на прилеглих до лісових смуг полях також відбувається завдяки додатковому надходженню 3 добривами речовин органіч- ного та мінерального походження (Rozhkov et al., 2015). Однак в захисному насадженні органічні сполуки надходять здебільшого від щорічного опаду і завдяки систематичному процесові його мінералізації. Мікроорганізми, які культивуються на КАА, сприяють зниженню вимивання азоту за межі грунтового профілю (Valetska, 2015).

Чисельність мікроорганізмів, які культивуються на КАА, тобто мікроорганізми, що перетворюють мінеральні сполуки азоту, була найменшою у лісовій смузі та на відстані $1 H$ від неї - 10,32 млн КУО/г грунту. Зі збільшенням відстані до/від смуги чисельність мікроорганізмів поступово зростає і досягає свого піку з навітряного боку на відстані $5 H$ та на відстані $10 H$ з завітряного боку. Ці зони, з агролісомеліоративного погляду, є найефективнішими в регулюванні гідротермічного i вітрового режимів на прилеглих полях, про що свідчить збільшення інтенсивності мінералізації органічних речовин мікроорганізмами. У цьому випадку, на завітряному боці спостерігаємо стабільнішу чисельність мікробіологічних груп і загалом дещо вищу, порівняно 3 варіантами навітряного боку. Також зосередили увагу на межі "зони пригнічення", що створюється лісовою смугою (0-2,5 H) і характеризувалася незначною кількістю організмів, що засвоюють азот від 10,32 до 15,96 млн КУО/г грунту.

Чисельність оліготрофної мікрофлори з віддаленням від узлісся полезахисної смуги збільшувалась, що свідчить про зменшення кількості поживних речовин, які необхідні для життєдіяльності грунтового мікробоценозу, оскільки оліготрофна мікрофлора інтенсивно розвивається на збіднених грунтах, що зумовлено їх трофічною специфічністю та відсутністю конкуренції.

Чисельність оліготрофних організмів була найменшою у грунті під захисним насадженням - 12,46 млн КУО/г грунту У зоні негативного впливу лісосмуг на сільськогосподарські культури (на відстані 0-2 $H$ ) як із завітряного, так і з навітряного боку чисельність оліготрофів була незначною і змінювалася від 13,15 до 16,54. Тобто з віддаленням від смуги збільшується і чисельність оліготрофів, що свідчить про погіршення трофічного режиму грунту. Подібні характеристики було наведено в роботі Symochko, Tsykun \& Symochko (2008), але відмінність полягала лише в тому, що залежність чисельності мікроорганізмів різних еколого-трофічних груп та показників оліготрофності грунту залежала від висоти лісових масивів. 
Rokytianskyi \& Makliuk (2014, 2016) у своїх працях наголошували на тому, що оліготрофна мікрофлора розвивається завдяки мінімальній кількості органічної речовини і притаманна останнім стадіям мінералізації, i іiі збільшення може свідчити про погіршення трофічного режиму грунту.

Поліпшення чисельності мікробоценозу грунту передбачає підвищення родючості грунтів (Robin et al., 1995). Агрофітоценоз дослідної території показав значне збільшення мікробної активності грунтів. Чисельність бактерій, актиноміцетів і грибів мали статистично значущі відмінності на різних відстанях від полезахисного насадження. Помітне збільшення відзначали також вчені Dłużniewska \& Mazurek (2011) в колоніях бактерій зі зростанням відстані від 30-річних захисних смуг робінії псевдоакації (0-2 м від насадження - 8 млн КУО/г грунту, 4-6 м - 24 млн КУО/Г грунту та 10-12 м - 38 млн КУО/г грунту).

Гриби $є$ одним із головних чинників біологічного розкладання органічних речовин, внаслідок чого утворюють різні сполуки, що залучаються до обміну поживних речовин рослинами (Sliusar \& Oksymets, 2014). Проведеними дослідженнями встановлено, що чисельність мікроскопічних грибів у грунті полезахисної смуги та на різних відстанях від неї варіював у межах 12,42-29,22 млн КУО/г грунту.

Під час дослідження біорізноманіття грунтової мікрофлори лісових біогеоценозів, Kulik (2005) акцентує увагу на підстилці насаджень і вмісті в ній мікробних організмів, а саме: бактерій, актиноміцетів і грибів. Він пов'язує їхню чисельність 3 різною світловою структурою насадження. У дубових насадженнях із тіньовою структурою відзначено більший вміст мікрофлори 3 переважанням у складі сапрофітних бактерій. У насадженні робінії звичайної (Robinia pseudoacacia L.) 3 на- півосвітленою світловою структурою встановлено значно більше актиноміцетів і грибів.

Дослідженнями Kryvolutskoho (1991) встановлено, що сумарну біологічну активність часто використовують як критерій оцінювання мінералізації органічної речовини грунту. Незважаючи на значні показники коефіцієнтів мінералізації та коефіцієнтів трансформації у грунті під насадженням та в "зоні пригнічення", виявлено, що сумарна біологічна активність була меншою під наметом лісової смуги - 34,29 млн КУО/г грунту та в зоні максимального пригніченого впливу смуги $1 \mathrm{H}$ 30,96 млн КУО/г грунту. Незначне збільшення сумарної біологічної активності визначено на відстані $2 \mathrm{H}$ 38,41 млн КУО/г грунту. Максимальні значення цього показника виявлено в полі на відстані $10 \mathrm{H}-58,86$ млн КУО/г грунту та на 5 H з навітряного боку - 61,04 млн КУО/г грунту.

Для того, щоб оцінити спрямованість мікробіологічних процесів у грунті полезахисної смуги, здійснювали розрахунок показників оліготрофності, мінералізації та показник трансформації органічних речовин (табл. 2). Найвищий показник мінералізації виявили на відстані 5-10 $H-1,63-2,05$, мінімальні - у грунті під лісовим насадженням - 0,96. Пояснюємо такий показник переважанням деструкції органічної речовини над ії синтезом.

Показник оліготрофності, розрахований для різних варіантів, збільшувався пропорційно відстані від лісового насадження, порівняно зі значенням 0,57 для центральної частини смуги. Такі показники характеризують збільшення частини легкодоступних органічних сполук. Більш низькі значення показника мінералізації і коефіцієнта МТОРГ свідчать про послаблення мінералізаційної функції мікробного ценозу й інтенсивності перебігу процесів трансформації органічної речовини.

Табл. 2. Спрямованість мікробіологічних процесів у грунті на різних відстанях до/від лісової смуги

\begin{tabular}{|c|c|c|c|c|c|}
\hline \multirow{2}{*}{ № варіанта } & Бік & $\begin{array}{c}\text { Відстань від } \\
\text { лісової смуги, м }\end{array}$ & $\begin{array}{c}\text { Коефіцієнт } \\
\text { оліготрофності }\end{array}$ & $\begin{array}{c}\text { Коефіцієнт } \\
\text { мінералізації }\end{array}$ & $\begin{array}{c}\text { Показник мікробної } \\
\text { трансформації органічних } \\
\text { речовин (МТОРГ) }\end{array}$ \\
\hline $10 \mathrm{H}$ & завітряний & 228,0 & 0,90 & 2,05 & 14,93 \\
\hline $7 \mathrm{H}$ & завітряний & 159,6 & 0,99 & 1,63 & 18,21 \\
\hline $5 \mathrm{H}$ & завітряний & 114,0 & 0,89 & 1,68 & 17,63 \\
\hline $2 \mathrm{H}$ & завітряний & 45,6 & 0,76 & 1,61 & 13,59 \\
\hline $1 \mathrm{H}$ & завітряний & 22,8 & 0,74 & 1,38 & 12,93 \\
\hline $0 \mathrm{H}$ & у смузі & 0 & 0,57 & 0,96 & 12,79 \\
\hline $1 \mathrm{H}$ & навітряний & 22,8 & 0,70 & 1,38 & 13,96 \\
\hline $2 \mathrm{H}$ & навітряний & 45,6 & 0,61 & 1,73 & 18,61 \\
\hline $5 \mathrm{H}$ & навітряний & 114,0 & 0,62 & 1,96 & 14,66 \\
\hline Відкрите поле & контроль & 342,0 & 0,59 & 1,56 & $\mathbf{2 , 4 8}$ \\
\hline $\boldsymbol{H І P}_{\mathbf{0 . 0 5}}$ & - & - & $\mathbf{0 , 1 1}$ & $\mathbf{0 , 2 5}$ & \\
\hline
\end{tabular}

Сприятливіші умови накопичення органічної речовини створюються на відстані від лісової смуги в межах 0-1 H (завітряний та навітряний бік), де коефіцієнт мінералізації коливається у межах 0,96-1,38, що свідчить про оптимізацію процесів мінералізації грунту у цій зоні. Саме тут формувалися оптимальні умови для інтенсивного накопичення органічної речовини, адже як у самій лісовій смузі, так і на відстані до $1 H$ обробіток грунту не проводили, а наземну фітомасу не вилучали (на відміну від поля, де зі збором урожаю вилучали практично всю наземну органіку), що призводило до мінералізації гумусу.

Показник мікробної трансформації органічної речовини грунту (МТОРГ) в зоні дослідження мав тенден- цію до зменшення на більшій відстані від смуги. Максимальне його значення зафіксовано у полезахисній лісовій смузі $(12,79)$, у зоні пригнічення сільськогосподарських культур $(0-1 H)-12,93-13,96$ та на відстані $2 H-13,59-14,61$. У зоні далі $2 H$ від смуги показник МТОРГ коливався у межах 17,63-18,86, і такі незначні відмінності були статистично не достовірними (за $\left.H I P_{0,05}\right)$. За результатами проведеного кореляційного та регресійного аналізу виявлено обернений зворотний помірний кореляційний зв'язок між зміною коефіцієнта мікробної трансформації та збільшенням відстані до лісової смуги: для завітряного боку $-R^{2}=0,8 ; r=-0,89$; $n=18 ; p=0,05$; для навітряного боку $-R^{2}=0,76 ; r=-$ 0,$87 ; n=12 ; p=0,05$. У роботах Малиновської також 
відзначено подібну тенденцію (Malynovska 2008, 2015), коли інтенсивність освоєння органічної речовини і мінералізації азотовмісних сполук вища, а активність мінералізації гумусових сполук нижча за відповідні показники екстенсивного агрозему.

Кількісний склад і співвідношення окремих представників у мікробному ценозі грунту значно залежить від способу обробітку грунту, - зазначає у своїй роботі Makliuk (2011). Надходження у грунт рослинних решток передусім трансформуються під впливом бактерій $і$ мікроскопічних грибів, а на пізніших стадіях цього процесу - актиноміцетів.

Щоб врахувати коливання показників за окремими групами і надати загальну оцінку за варіантами досліду розрахували інтегрований показник біогенності (ІПБ). Встановили максимальні показники біогенності ріллі 79,78-95,70\%, що пояснюємо комплексом чинників (активізацією кореневих систем сільськогосподарських рослин, обробітком грунту, внесенням добрив та іншими елементами агротехніки). Окрім цього, внесення мінеральних добрив, яке практикується на досліджуваних полях, також призводить до активізації біогенності грунту (Rozhkov et al., 2015). Значно нижчу біогенність виявлено на відстані $1 H-2 H$ із завітряного і навітряного боків лісової смуги, у межах менш активної зони. Як зазначали раніше, ці приузлісні ділянки, які обмежуються як наземними, так і підземними частинами деревних рослин, вирізняються конкурентною спроможністю за вологу та поживні речовини.

Висновки. 3 виконаних досліджень видно, що завдяки меліоративному ефекту формується сприятливий мікробіологічний режим, порівняно з відкритим незахищеним полем, та встановлюється властивий для зони інтенсифікації еколого-трофічний склад аеробних організмів.

Мікробіологічні грунтоутворювальні процеси у грунті під наметом полезахисної лісової смуги та на приузлісних ділянках до $2 H$ сприяють накопиченню органічної речовини, а мікробна трансформація органічної речовини наближається до рівня природних процесів грунтів чорноземного типу. Незважаючи на це, сумарна біологічна активність відносно вища у відкритому полі (контроль) і збільшується з віддаленням від лісової смуги. Ірунтоутворювальні процеси на ріллі виявилися оптимальними для агролісоландшафту, оскільки спрямованість мікробіологічних процесів у грунті залежала від агротехнічних прийомів, які використовували у зоні найефективнішого впливу лісових смуг (510 H). Також причиною вищої біологічної активності у грунті на ріллі є щорічний обробіток грунту і збільшення доступу кисню в орному шарі грунту, та внесення мінеральних добрив, що викликає пришвидшений розвиток агрономічно корисних мікроорганізмів.

Враховуючи особливості зони пригнічення в узлісних частинах лісової смуги, доцільно іiі вилучати 3 польової сівозміни і використовувати як осередки трав'яної рослинності, де, як відомо, формується корисний ентомокомплекс для запилення польових культур та поширення ентомофагів.

\section{Перелік використаних джерел}

Acci, Dzh. (1959). Agricultural ecology. Moscow: Inostrannaya literatura, 295 p. [In Russian].
Aristovskaya, T. V., \& Hudyakova, Yu. A. (1977). Methods of studying the soil microflora and its activity. Methods stationary study soil. Moscow: Science, (pp. 141-286). [In Russian].

Bardgett, R. D., \& van der Putten, W. H. (2014). Belowground biodiversity and ecosystem functioning. Nature 515, 505-511. https://doi.org/10.1038/nature13855

Bieliñska, J. E., Futa, B., \& Mocek, A. (2008). Inynieria Rolnicza, 10(108), 7. Budziak, O. S. (2014). Degradation and revitalization measures of the lands of Ukraine. Zemleustrii, kadastr i monitorynh zemel, 1-2, 57-64. [In Ukrainian].

Cavagnaro, T. R., Cunningham, S. C., \& Fitzpatrick, S. (2016). Pastures to woodlands: changes in soil microbial communities and carbon following reforestation. Appl. Soil Ecol., 107, 24-32. https://doi.org/10.1016/j.apsoi1.2016.05.003

Coe, R., Njoloma, J., \& Sinclair, F. (2016). Loading the dice in favour of farmer: reducing the risk of agronomic innovations. Exp. Agric., 1-17. https://doi.org/10.1017/S0014479716000181

Dłużniewska, J., \& Mazurek, R. (2011). Effect of extracts of soils from various distances from black locust (Robinia pseudoaccacia) shelterbelts on Trichoderma fungi. Ecological Chemistry and Engineering A, 18(5-6), 679-684.

Doni, S., Macci, C., Longo, V., Souid, A., Garcia, C., \& Masciandaro, G. (2017). Innovative system for biochemical monitoring of degraded soils restoration. Catena, 152, 173-181. https://doi.org/10.1016/j.catena.2017.01.016

DSTU 7847:2015. (2016). Soil quality. Determination of the number of microorganisms in the soil by planting a solid (agar) culture medium, from 01 Jul 2016. Kiev: UkrNDNTs, III, 12 p. [In Ukrainian].

Gu, F. X., Pan, X. L., Pan, B. R., et al., (2002). Changing of aeolian soil fertility in central Taklimakan desert under impact of artificial vegetation. Acta Ecologica Sinica, 22(8), 1179-1188.

Hakeem, K. R., Akhtar, J., \& Sabir, M. (Eds). (2016). Soil Science: Agricultural and Environmental Prospectives. (1st ed.). (Vol. 15). $430 \mathrm{p}$.

Horielov, O. M., Ellanska, N. E., Yunosheva, O. P., Horielov, O. O., \& Virovka, V. M. (2017). Biological activity of energy crops soil. Naukovi dopovidi NUBIP Ukrainy, 1. [In Ukrainian].

Kovalov, V. B., Romanchyk, L. D., Trembitska, O. I., \& Rybak, V. V. (2012). Cost-effectiveness of alternative systems of organic and mineral fertilizer in short rotational crop rotation. Ahropromyslove vyrobnytstvo Polissia, 5, 12-16. [In Ukrainian].

Krivoluckij, D. A. (1991). Bioindication and monitoring. Moscow: Science, 288 p. [In Russian].

Krokhin, S. V. (2012). Ecological state of black soil left-bank Ukraine steppe and steppe and its assessment on indicators of humus mode. Candidate dissertation for agricultural sciences (03.00.16 - Ekolohiia). Kharkiv, 221 p. [In Ukrainian].

Kryhanivskyi, V. H., \& Kostohryz, P. V. (2010). Biological activity of black podzolized soil at the end of five-course rotation in its dependence on the measures of basic soil cultivation. Bulletin of the Bila Tserkva State Agrarian University, 2(69), 16-18. [In Ukrainian].

Kulik, A. F. (2011). Microbiocenosis in soils of forest biogeocenoses of the Samara river Catchment. Bioriznomanittia ta rol tvaryn $v$ ekosystemakh: Proceedings of the 6th International Scientific Conference. (pp. 18-20). Dnipropetrovsk: Publishing House DNU. [In Ukrainian].

Lisovyi, M. M., \& Chaika, V. M. (2008). Ecological function of entomological biodiversity. Fauna of phytophagous insects of tree and shrub plantations of the Forest-Steppe of Ukraine. Kamianets-Podilskyi: Aksioma, 384 p. [In Ukrainian].

Makliuk, O. I. (2011). Using the potential of microbial soil in organic agriculture. Bulletin of Agricultural Science, 12, 52-54. [In Ukrainian].

Malynovska, I. M. (2008). Influence of type of phytocenosis on the orientation and intensity of microbiological processes in soil of perennial soil. (Ser. Biology). Journal of Vasyl Stefanyk Precarpathian National University, 11, 68-75. [In Ukrainian].

Malynovska, I. M., \& Tkachenko, M. A. (2015). The number of biochemical and physiological activity of microorganisms horizons of gray forest soils. Bulletin of the National Science Center "Institute of Agriculture of $N A A S^{\prime \prime}, 4,13-24$. [In Ukrainian]. 
Mechanism. (2017). Strategy to improve the mechanism to control the use and protection of agricultural land state property and disposal. Retrieved from: http://zakon3.rada.gov.ua/laws/show/413-2017$\% \mathrm{D} 0 \% \mathrm{BF} /$ page.

Muhammed, U. P. F. B., Sindhu, P. V., Gopal, K. S., \& Thomas, C. G. (2015). Influence of mulches on rhizosphere microflora, yield and weed competition in okra Abelmoschus esculentus (L.) Moench. J. Trop. Agric., 53, 70-74.

Mukha, V. D. (1980). About indicators reflecting the intensity and direction of soil processes. Sb. nauch. tr. Khark. s. $-k h$. yn-ta, 273, 1316. [In Russian].

Murray, P. J., Clegg, C. D., Crotty, F. V., de la Fuente Martinez, N., Williams, J. K., \& Blackshaw, R. P. (2009). Dissipation of bacterially derived $\mathrm{C}$ and $\mathrm{N}$ through the mesoand macrofauna of a grassland soil. Soil Biology and Biochemistry, 41, 1146-1150.

Murthy, I. K., Dutta, S, Vinisha, V., et al., (2016). Impact of agroforestry sytems on ecological and socioeconomic systems: a review. Glob J Sci Front Res: H Environ Earth Sci., 16(5), Version 1.0, no. 3:15-27.

Notaro, K., De Medeiros, E. V., Duda, G., Silva, A., \& De Moura, P. (2014). Agroforestry systems, nutrients in litter and microbial activity in soils cultivated with coffee at high altitude. Sci. Agric., 71, 87-95. https://doi.org/10.1590/S0103-90162014000200001

Patyka, V. P., \& Symochko, L. Yu. (2013). Microbiological monitoring of soil and natural ecosystems transformed Transcarpathian of Ukraine. Microbiological Journal, 75(2), 21-31. [In Ukrainian].

Rempel, J. C., Kulshreshtha, S. N., Amichev, B. Y., \& van Rees, K. C. (2016). Costs and benefits of shelterbelts: A review of producers' perceptions and mind map analyses for Saskatchewan. Canadian Journal of Soil Science, 97(3), 341-352.

Report. (2019). The National Report on the State of Environment in Ukraine in 2012. Retrieved from: http://www.menr.gov.ua/index.php/dopovidi. [In Ukrainian].

Rokytianskyi, A. B. (2016). Particularities of changes in microbial communities of chernozem podzolized under two-years application of herbicides different danger class. Ahrokhimiia i gruntoznavstvo, 85, 130-136. [In Ukrainian].

Rokytianskyi, A. B., \& Makliuk, O. I. (2015). The transformation of microbial coenosis podzolic chernozem under the joint application of microbial product and herbicides in soybean growing technology. Biolohiia ta ekolohiia gruntiv. Lviv, 88 p. [In Ukrainian].

Rozhkov, A. O., Puzik, V. K., Kalenska, S. M., et al., (2015). Performance management of hard spring wheat crop in the Left Bank and Northern Forest Steppe of Ukraine. Kharkiv: Maidan, 354 p. [In Ukrainian].

Shah, A. N., Tanveer, M., Shahzad, B., et al. (2017). Environ Sci Pollut Res, 24, 10056. https://doi.org/10.1007/s11356-017-8421-y

Sliusar, S. M., \& Oksymets, O. L. (2014). Biological activity of dark gray podzolized soil for Sudan sorghum cultivation. Bulletin of the National Science Center "Institute of Agriculture of NAAS", 3, 134 141. [In Ukrainian].

Sudmeyer, R., Bicknell, D., \& Coles, N. (2007). Tree windbreaks in the wheatbelt. Department of Agriculture and Food, Western Australia, Perth. Bulletin 4723.

Sustainable Use. (2012). The strategy of sustainable use, restoration and management of soil resources of Ukraine. (Sect. 5.8 Optimizing the biological condition of the soil). Kiev: Agrarian science. [In Ukrainian].

Sven Erik Jørgensen. (2009). "Ecological Models that Adapt", Denmark.dk, Retrieved May 4.

Symochko, L. Yu., Tsykun, T. V., \& Symochko, V. V. (2008). Oligotrophic and pedotrophic indicators of the virgin soil of the Shirokoluzhansky massif of the Carpathian Biosphere Reserve. (Ser. Biology). Scientific Bulletin of Uzhhorod University, 24, 91-95. Uzhhorod: Publishing House UzhNU "Hoverla". [In Ukrainian].

Valetska, O. V., \& Havryliuk, V. A. (2015). The dynamics of nitrogen cycle microorganisms number in sod-podzolic consolidated sandy soil as influenced by fertilization. Naukovi pratsi Instytutu bioenerhetychnykh kultur i tsukrovykh buriakiv, 23, 139-143. [In Ukrainian].

Von Holle, B., Joseph, K. A., Largay, E. F., \& Lohnes, R. G. (2006). Facilitations between the introduced nitrogen-fixing tree, Robinia pseudoacacia, and nonnative plant species in the glacial outwash upland ecosystem of Cape Cod, MA. Biodiversity and Conservation, 15, 2197-2215.

Wall, D. H., Nielsen, U. N., \& Six, J. (2015). Soil biodiversity and human health. Nature, 528, 69-76. https://doi.org/10.1038/nature15744

\section{S. V. Sydorenko1, O. I. Starchenko², H. B. Hladun', S. H. Sydorenko}

${ }^{I}$ G.M. Vysotskiy Ukrainian Research Institute of Forestry and Forest Melioration, Kharkiv, Ukraine ${ }^{2}$ National Scientific Center "Institute for Soil Science and Agrochemistry named after O.N. Sokolovsky", Kharkiv, Ukraine ${ }^{3}$ Kharkiv Petro Vasylenko National Technical University of Agriculture, Kharkiv, Ukraine

\section{THE INFLUENCE OF OAK SHELTERBELTS ON THE BIOGENESITY OF TYPICAL AGROGENIC CHORNOZEM (BLACK SOIL)}

The peculiarities of soil biogenesity in the conditions of agricultural development in the zone of shelterbelt impact are considered. The specific regime of microbiological processes intensity and direction were compared with the open field (which was a control) and forest phytocenosis. The biological activity of the soil by the numerosity and ratio of the main agronomically important groups of microorganisms of typical black soil is estimated. There is a tendency in activation of the spatial structure of microbial cenosis in the direction from the edge of the shelterbelt and to the center of the field: with increasing distance from the tree stand the numerosity of oligotrophs increases, which indicates an increase in the part of readily available organic compounds. Among all groups, the highest abundance was found among oligotrophic microorganisms (maximum $-29.22 \mathrm{million} \mathrm{CFU} / \mathrm{g}$ soil on the leeward side of the shelterbelt, minimum - 22.94 million CFU/g soil on the windward side). A significant numerosity of microorganisms that absorb mineral nitrogen (18.56-24.56 million CFU/g of soil) were concentrated from both the upside and the windward sides. Such indicators are conditioned by the agrotechnical treatments on the field in comparison with the soil under shelterbelt, where no agrotechnical treatments have been taken since their creation. Favorable conditions for the accumulation of organic matter in terms of mineralization at a distance from the forest strip to $10 \mathrm{H}$ have been revealed, which testifies to the optimization of soil mineralization processes. Transformation coefficients revealed disturbance of soil-forming processes on arable land and their imbalance. It was found that the indicator of microbial transformation of soil organic matter in the study area tended to decrease at a greater distance from the shelterbelt.

Keywords: shelterbelt; ecological-trophic groups; biogenesity of soil; protective height; windward side; upside. 